\title{
Labour Productivity Dynamics Regularities Analyses by Manufacturing in European Union
}

\author{
Lembo Tanning \\ Tallinn, Estonia, EU, Estonia \\ Toivo Tanning \\ Tallinn, Estonia, EU, Estonia
}

\begin{abstract}
The aim of the article is to analyse labour productivity key indicators of manufacturing or working efficiency of European Union (EU), it the theoretical bases and the regularities of these changes. We use regression analysis. Knowledge of the regularities of labour productivity changes allows predicting future changes and make optimal business decisions. The basis is gross domestic product (GDP) analysis. We will analyse labour productivity by turnover and gross value added per person employed of manufacturing total and partly by countries, but also GDP per capita. Taking the basis this publication and the previous works of the authors, draws conclusions and suggestions.
\end{abstract}

Keywords: Theoretical bases of changes labour productivity; Regression analysis; GDP analysis; Manufacturing; European Union.

Scientific Novelty: Analysis labour productivity changes laws of manufacturing.

(ㄷ) (1) CC BY: Creative Commons Attribution License 4.0

\section{Introduction}

We will make an introduction a brief overview of development and background of manufacturing. As industry has been the basis of their wealth, then we will analyse the main indicators of industrial development.

Manufacturing is the production of goods for use or sale using labour and machines, tools, chemical and biological processing, or formulation. The term may refer to a range of human activity, from handicraft to high tech, but is most commonly applied to industrial production, in which raw materials are transformed into finished goods on a large scale (Manufacturing).

In its earliest form, manufacturing was usually carried out by a single skilled artisan with assistants. Training was by apprenticeship. In much of the pre-industrial world, the guild system protected the privileges and trade secrets of urban artisans. Before the Industrial Revolution, most manufacturing occurred in rural areas, where household-based manufacturing served as a supplemental subsistence strategy to agriculture (and continues to do so in places). Entrepreneurs organized a number of manufacturing households into a single enterprise through the putting-out system. Toll manufacturing is an arrangement whereby a first firm with specialized equipment processes raw materials or semi-finished goods for a second firm (Manufacturing; Tanning and Tanning, 2015).

The aim of the article is to analyse labour productivity of manufacturing of EU, it the theoretical bases and the regularities of these changes.

\section{Methodology and Theoretical Bases}

In statistical modeling, regression analysis is a set of statistical processes for estimating the relationships among variables. It includes many techniques for modeling and analyzing several variables, when the focus is on the relationship between a dependent variable and one or more independent variables. More specifically, regression analysis helps one understand how the typical value of the dependent variable changes when any one of the independent variables is varied, while the other independent variables are held fixed (Extrapolation Methods, 1991; Scott Armstrong et al., 2004; Zhao et al., 2011).

Regression models predict a value of the $\mathrm{Y}$ variable given known values of the $\mathrm{X}$ variables. Prediction within the range of values in the dataset used for model-fitting is known informally as interpolation. Prediction outside this range of the data is known as extrapolation. Performing extrapolation relies strongly on the regression assumptions. The further the extrapolation goes outside the data, the more room there is for the model to fail due to differences between the assumptions and the sample data or the true values (Freedman, 2005; Lindley, 1987).

A polynomial curve can be created through the entire known data or just near the end. The resulting curve can then be extended beyond the end of the known data. Polynomial extrapolation is typically done by means of Lagrange interpolation. The resulting polynomial is used to extrapolate the data (Extrapolation Methods, 1991; Freedman, 2005; Lindley, 1987; Scott Armstrong et al., 2004; Zhao et al., 2011).

In statistics, nonlinear regression is a form of regression analysis in which observational data are modeled by a function which is a nonlinear combination of the model parameters and depends on one or more independent variables. The data are fitted by a method of successive approximations. 
Regression analysis is a statistical method for studying the influence of one or several independent variables $\mathrm{X}_{1}$, $\mathrm{X}_{2}, \ldots, \mathrm{X}_{\mathrm{p}}$ to the dependent variable $\mathrm{Y}$. Independent variables are otherwise called regressors or predictors, and dependent variables are criterion variables. The terminology of dependent and independent variables reflects only the mathematical dependence of the variables, and not cause-effect relationships (Ash, 2009; Bethea et al., 1985; Dodge, 2003; Meade and Islam, 1995; Schittkowski, 2002; Seber and Wild, 1989; Wooldridge, 2012).

\subsection{Regression Analysis Goals}

1. Determination of the degree of determinism of the criterion (dependent) variable predictors (independent variables)

2. Predict the value of the dependent variable using independent (s)

3. Determination of the contribution of individual independent variables to the variation of the dependent.

In mathematical modeling, the dependent variable is studied to see if and how much it varies as the independent variables vary. In the simple stochastic linear model $\mathrm{y}_{\mathrm{i}}=\mathrm{a}+\mathrm{bx}_{\mathrm{i}}+\mathrm{e}_{\mathrm{i}}$ the term $\mathrm{y}_{\mathrm{i}}$ is the $i^{\text {th }}$ value of the dependent variable and $\mathrm{x}_{\mathrm{i}}$ is the $i^{\text {th }}$ value of the independent variable. The term $\mathrm{e}_{\mathrm{i}}$ is known as the "error" and contains the variability of the dependent variable not explained by the independent variable.

With multiple independent variables, the model is $\mathrm{y}_{\mathrm{i}}=\mathrm{a}+\mathrm{bx}_{1, \mathrm{i}}+\mathrm{bx}_{2, \mathrm{i}}+\ldots+\mathrm{b} \mathrm{x}_{\mathrm{n}, \mathrm{i}}+\mathrm{e}_{\mathrm{i}}$, where $n$ is the number of independent variables (Ash, 2009; Dodge, 2003; Wooldridge, 2012).

The techniques and labour market survey definitions used by the authors have been specified in OECD (Productivity) and Eurostat (Methodological Notes, 2011). The measures of labour productivity are presented as indices and as rates of change. Labour productivity are indirectly GDP per capita, here, however turnover per person employed and apparent labour productivity (Gross value added per person employed) (Gross Domestic Product At Current Prices). Formulas of productivity measures (Formulas of Productivity Measures, 2018; Tanning T. and Tanning, 2014g).

Labour productivity per person employed (on the basis of value added) - indicates how much value added is generated on average per person employed (is calculated as value added divided by the number of persons employed) (Methodological Notes, 2011). GDP is an indicator for a nation's economic situation and a measure of the economic activity. It reflects the total value of all goods and services produced. Expressing GDP in PPS (purchasing power standards) eliminates differences in price levels between countries, and calculations on a per head basis allows for the comparison of economies significantly different in absolute size (Methodology). GDP per capita in constant prices constant prices GDP is found and the ratio of the average population. Often used in constant prices GDP as an indicator of the wealth of nations, as it reflects the average real income in this country.

GDP per person employed is intended to give an overall impression of the productivity of national economies expressed in relation to the EU average. The volume index of GDP per capita in PPS is expressed in relation to the EU average set to equal 100. Basic figures are expressed in PPS, i.e. a common currency that eliminates the differences in price levels between countries allowing meaningful volume comparisons of GDP between countries (Gross Domestic Product At Current Prices; Methodological Notes, 2011).

Source data based on structural business statistics, there are a total of 24 activities (sectors) (Structural Business Statistics Introduced). Statistical classification of economic activities in the European Community, abbreviated as NACE, is the nomenclature of economic activities in the EU. This article presents an overview of the EU manufacturing sector, which is included in NACE Rev. 2 Section C (Annual Detailed Enterprise Statistics for Industry, 2018).

The theoretical bases of labour productivity have been brought in more detail in the authors book (Tanning L. and Tanning, 2008;2009; Tanning and Tanning, 2015), in authors' earlier works (Tanning L. and Tanning, 2012;2013a; Tanning T. and Tanning, 2013d; Tanning T. and Tanning, 2013e; Tanning L. and Tanning, 2013b; Tanning T. and Tanning, 2013f; Tanning L. and Tanning, 2013c;2014a;2014b;2014c;2014f;2014d;2014e; Tanning T. and Tanning, 2014h; Tanning T., 2017a;2017b; Tanning L. and Tanning, 2018a;2018b;2018c) and in the works of other authors (Kalle, 2013; Saari, 2011). All figures are the authors' illustration.

\section{Gross Domestic Product at Market Prices}

For an introduction, let us look at the background the GDP (gross domestic product) at market prices and PPS, but also GDP per capita.

Table-1. GDP at current prices, billion euro (Gross Domestic Product At Current Prices)

\begin{tabular}{l|l|l|l|l|l|l|l|l}
\hline & $\mathbf{2 0 0 5}$ & $\mathbf{2 0 0 7}$ & $\mathbf{2 0 0 9}$ & $\mathbf{2 0 1 1}$ & $\mathbf{2 0 1 3}$ & $\mathbf{2 0 1 5}$ & $\mathbf{2 0 1 6}$ & $\mathbf{2 0 1 7}$ \\
\hline Germany & 2,300 & 2,513 & 2,460 & 2,703 & 2,826 & 3,043 & 3,144 & 3,263 \\
\hline Spain & 930 & 1,080 & 1,079 & 1,070 & 1,025 & 1,079 & 1,118 & 1,164 \\
\hline France & 1,771 & 1,945 & 1,939 & 2,059 & 2,115 & 2,194 & 2,228 & 2,288 \\
\hline Italy & 1,489 & 1,609 & 1,572 & 1,637 & 1,604 & 1,652 & 1,680 & 1,717 \\
\hline UK & 2,027 & 2,245 & 1,716 & 1,883 & 2,063 & 2,602 & 2,393 & 2,324 \\
\hline
\end{tabular}


Figure-1. GDP at market prices, current prices, billion PPS (Gross Domestic Product At Current Prices)

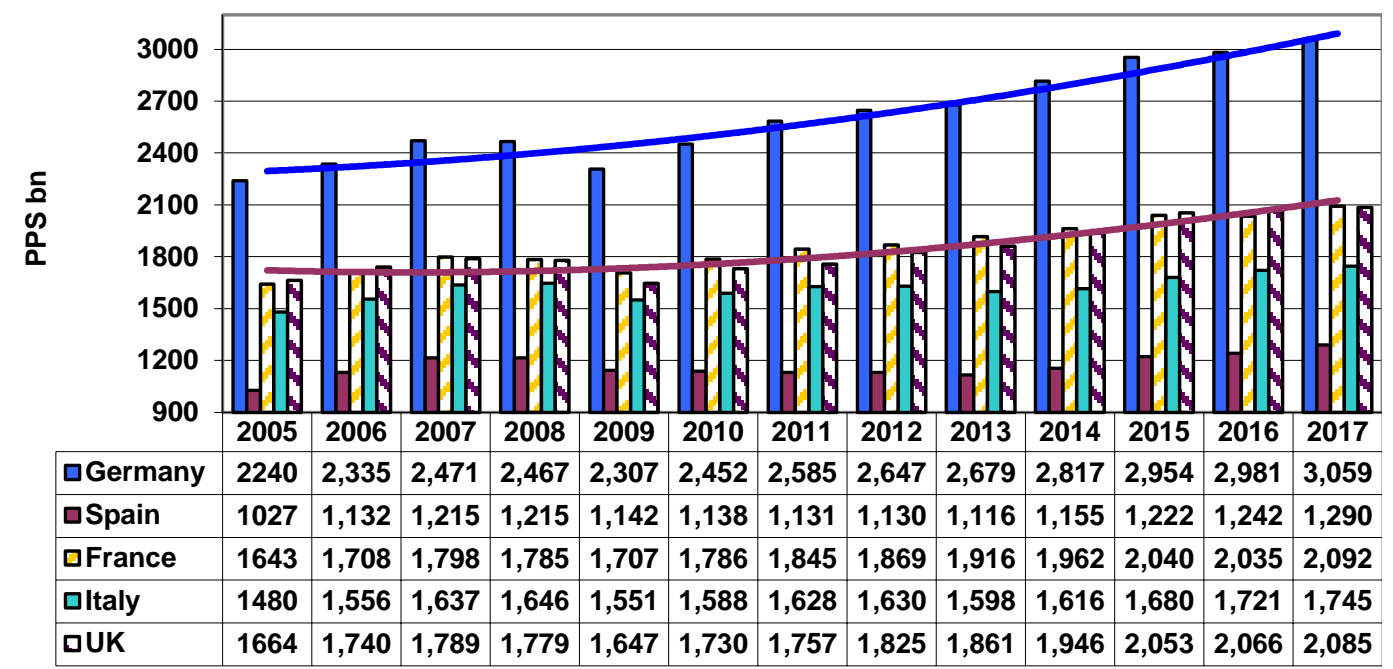

Relatively simple theoretical trend lines (2nd and 3rd degree polynomials), which are very high $\mathrm{R}^{2}$, indicate the period 2005-2017 both in Germany and the UK relative stable development of the economy, despite the 2009 downturn.

It was in 2017 largest by current prices in Germany, 3277 billion; in UK, 2332 billion; France, 2292 billion and in Italy 1725 billion EUR. Largest by PPS prices was in Germany, 3059 billion; in UK, 2085 billion; in France, 2092 billion; in Italy 1745 billion and in Spain, 1290 billion PPS.

Germany by GDP (PPS) is 1.5 times stronger than the UK and France. In the years 2007-2014 France was stronger than the UK, but the difference between UK and France in 2015 was 59 million euros $(0.003 \%)$ and in 2016 $=39.33$ billion euros (1.902\%). In 2017 by PPS was stronger France than the UK and by current prices UK than France.

Figure-2. GDP at market prices, current prices, euro per capita (Gross Domestic Product At Current Prices)

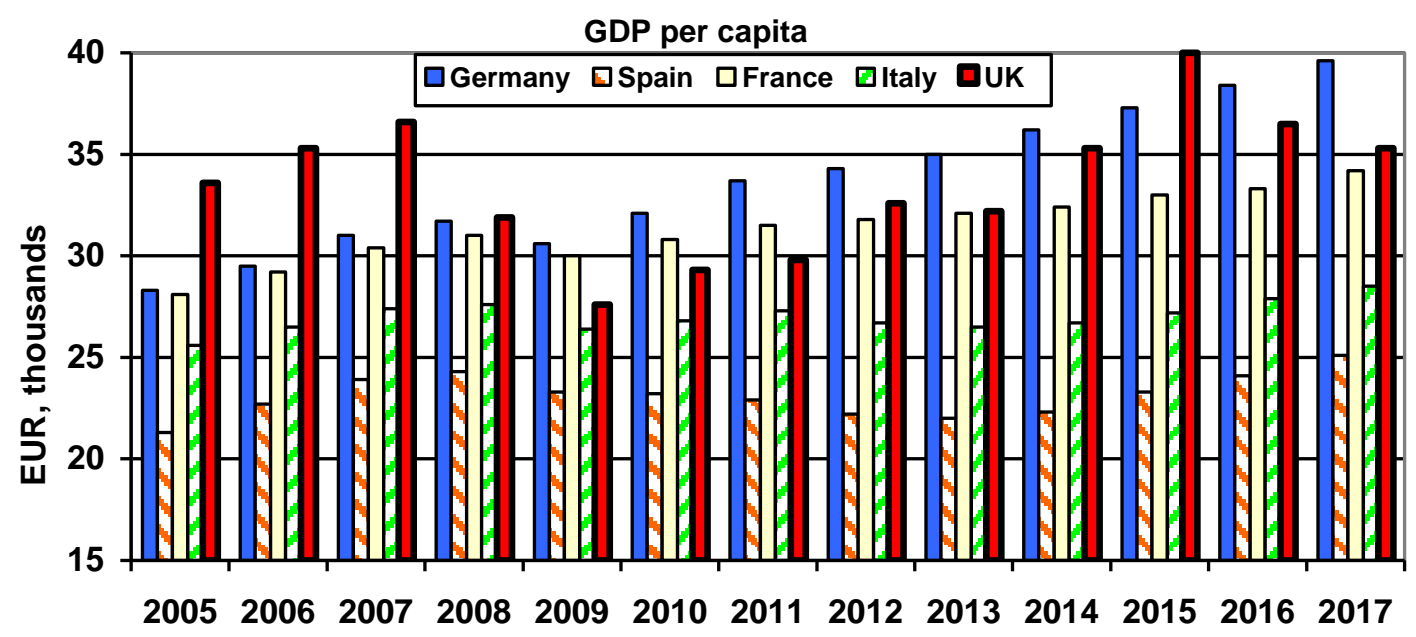

In 2017 were GDP per capita in Germany 39,600; in Spain 25,100; in France 34,100; in Italy 28,500 and in UK 35,300 euro. In 2015 was GDP per capita in UK 40,000 euro.

In the case of the EU's great powers, UK GDP per capita was the largest in the years 2005 - 2008 and 2015. In other years, Germany was superior to the great powers.

GDP per capita of UK $(36,500)$ is larger than France, Italy and Spain, but less than Germany, other Central European and Nordic countries; 1.6 times smaller than Ireland. The average of the new EU member states and the EU-28 (29.100) GDP per capita is lower than the UK. The UK was ranked 10th in the 2016 EU ranking.

\section{Manufacturing of EU}

We will first observe the main total quantitative indicators of manufacturing, their changes.

In 2016 largest turnover or gross premiums written of manufacturing were in Germany 1951 billion; Italy 898 billion, France 852 billion, UK 683 billion and Spain, 466 billion EUR. 
Figure 3. Turnover of EU and Germany, in billion EUR (Gross Domestic Product At Current Prices)
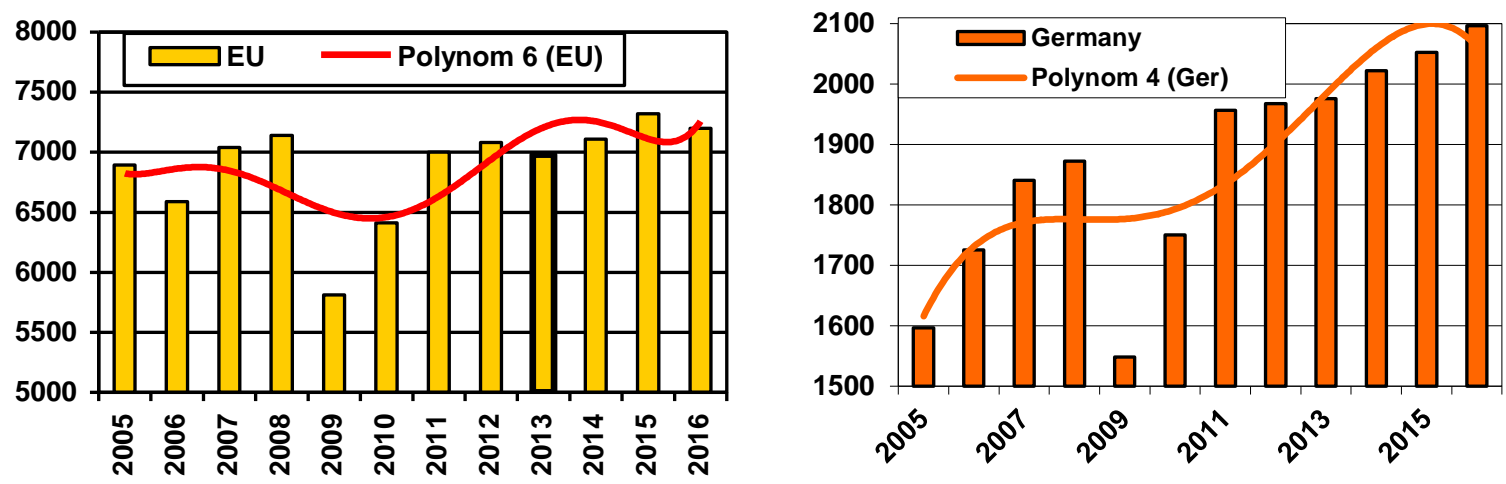

In 2009 the EU-27 decrease of the turnover was 1,336 billion EUR or about one-fifth. In the following year, while turnover increased, but in 2012 it was lower than in 2008. Thus, the turnover of the EU as a whole had not yet gone out of the economic crisis. It was only in 2013 exceeded strongly the level during the boom.

With biggest turnover in Germany was the same trend. In 2009 the decline was $17.3 \%$. In the following years, however, was a big gain, but still remained at the 2011 level of just under (0.33\%) yet to 2008 levels.

In 2016 largest production of manufacturing was in Germany 1738 billion, in Italy 889 billion, in France 763 billion and in UK 683 billion EUR.

Figure-4. Production value of enterprises of EU countries (Gross Domestic Product At Current Prices) Produktion value of manufaktuturing

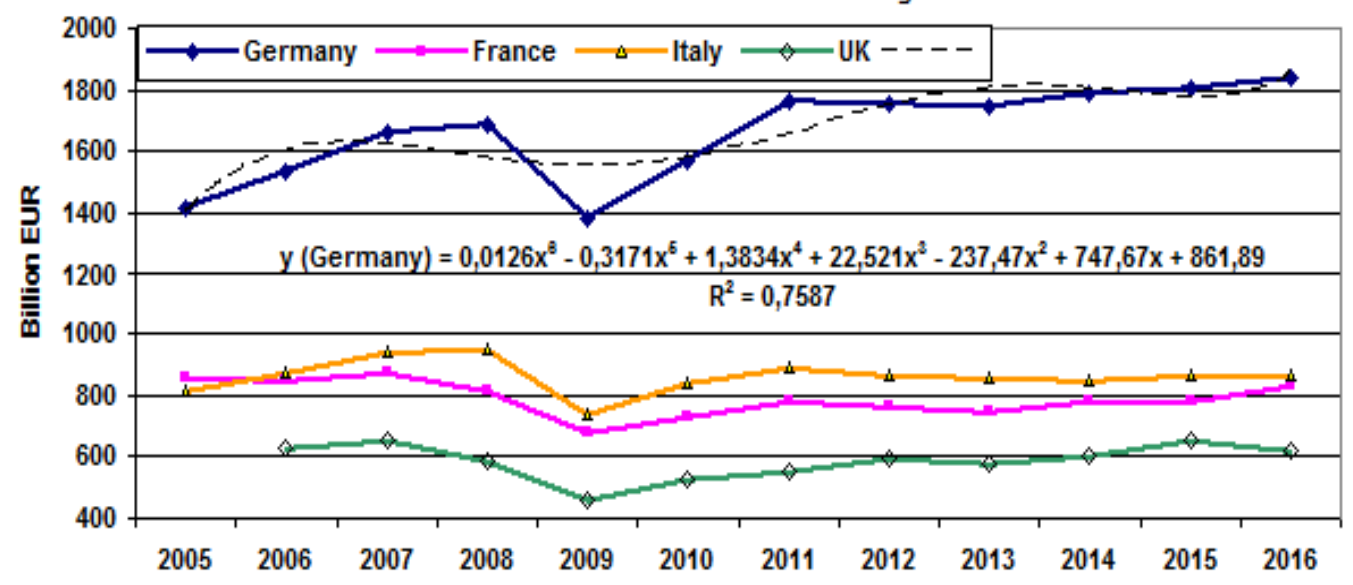

The first decline of EU-27 production value of the manufacturing in test period has already in $2006(-4.7 \%)$. Also, in 2008 was small decrease (-0.3\%). In 2009, the EU annual decline was 1.3 trillion or 19.9\%, and in 2012 it was not yet reached the level of 2008. In 2013 has already exceeded the 2007 level by $8.0 \%$. Basically, the same trend was also the big countries, with the exception of Germany. In Germany and Sweden was in 2009 also a large decrease of production, but in 2011 exceeded strong pre-crisis levels. This trend applies from EU-15 countries also on Belgium, the Netherlands and Austria.

In 2016 largest value added at factor cost of enterprises of manufacturing were in Germany 535 billion, in UK 222 billion, in Italy 213 billion, in France 208 billion and in Spain 102 billion EUR.

Gross operating surplus of enterprises of manufacturing of EU was in 2005611 billion, in 2009 only 408 billion, but in 2015 already 714 billion EUR. In 2016 it was bigger in Germany 144 billion, UK 109 billion, Italy 81 billion, France 53 billion and Spain 40 billion EUR. In 2017 were it in Germany 173 billion, UK 96 billion, Italy 89 billion, France 59 billion and Spain 41 billion EUR (Gross Domestic Product At Current Prices).

Figure-5. Number of persons employees and employed of EU, thousands (Gross Domestic Product At Current Prices)

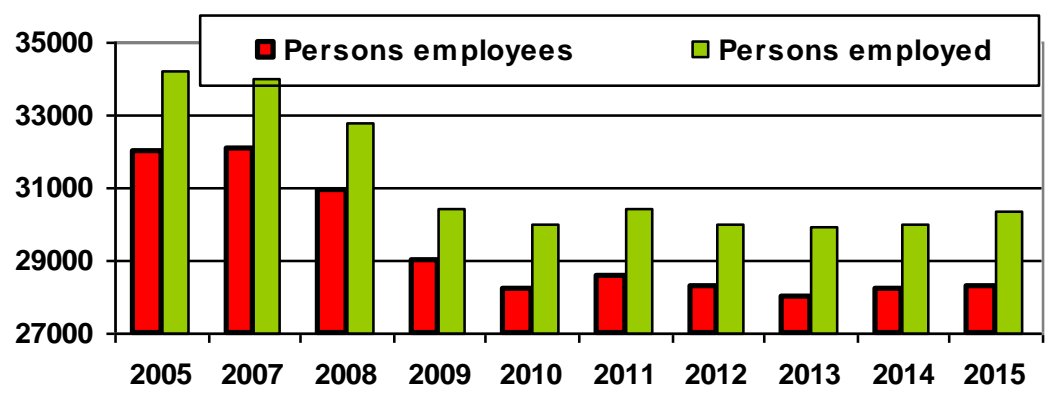


The highest number of persons employed of the EU was in 2005. Next, it is decreased continuously in 2015 from 2005 was fall $12.1 \%$. Number of persons employed of the EU is decreased nearly 4 million.

More than million workers of manufacturing companies are in eight the EU-28 members states, including Germany are nearly three times more likely than the UK. In 2015 number of persons employed of manufacturing were in Germany 7273 thousand, in Italy 3619 thousand, in France 2903 thousand, in Poland 2493 thousand, in UK 2498 thousand, in Spain 1769 thousand, in Czech Republic 1265 thousand and in Romania 1203 thousand. In 2016 were it in Germany 7361 thousand, in Italy 3662 thousand, in France 2906 thousand, in Poland 2584 thousand, in UK 2590 thousand, in Spain 1855 thousand, in Czech Republic 1294 thousand and in Romania 1210 thousand (Gross Domestic Product At Current Prices).

\section{Working Efficiency or Labour Productivity}

Table-2. Turnover per person employed of EU countries, thousands (Gross Domestic Product At Current Prices).

\begin{tabular}{|c|c|c|c|c|c|c|c|c|c|c|}
\hline & 2005 & 2008 & 2009 & 2010 & 2011 & 2012 & 2013 & 2014 & 2015 & 2016 \\
\hline Belgium & : & 450.9 & 379.4 & 441.5 & 502.5 & 515.9 & 519.7 & 518.1 & 473.1 & 498.0 \\
\hline Bulgaria & 26.1 & 40.1 & 34.2 & 41.1 & 47.3 & 50.5 & 52.2 & 52.3 & 53.4 & 53.7 \\
\hline Czech Rep & $:$ & 105.2 & 94.7 & 110.9 & 120.4 & 120.7 & 118.9 & 121.7 & 124.1 & 124.4 \\
\hline Denmark & : & 243.5 & 263.1 & 290.0 & 255.5 & 275.4 & 282.3 & 286.8 & 297.0 & 364.8 \\
\hline Germany & : & 263.6 & 231.1 & 252.8 & 274.1 & 274.4 & 273.6 & 278.1 & 282.1 & 284.7 \\
\hline Estonia & 48.4 & 69.7 & 62.9 & 82.0 & 100.2 & 101.3 & 106.6 & 107.6 & 106.3 & 109.1 \\
\hline Ireland & $:$ & 497.8 & 502.4 & 587.3 & 605.5 & 625.5 & 597.5 & 616.7 & 116.2 & 012.5 \\
\hline Greece & : & 155.3 & 136.9 & 149.9 & 170.7 & 187.1 & 195.3 & 202.0 & 173.5 & 150.3 \\
\hline Spain & $:$ & 224.5 & 200.6 & 221.9 & 243.7 & 253.1 & 257.6 & 264.5 & 264.0 & 251.3 \\
\hline France & : & : & : & 273.2 & 294.1 & 295.5 & 291.8 & 288.3 & 297.2 & 312.9 \\
\hline Croatia & : & 69.0 & 58.6 & 61.1 & 63.3 & 64.0 & 62.1 & 65.0 & 69.5 & 75.8 \\
\hline Italy & $:$ & 221.9 & 187.9 & 217.6 & 234.2 & 235.6 & 233.7 & 237.4 & 244.5 & 242.8 \\
\hline Cyprus & $:$ & 110.0 & 101.0 & 104.7 & 102.8 & 100.1 & 97.6 & 100.6 & 101.2 & 102.4 \\
\hline Latvia & 31.6 & 49.7 & 46.1 & 53.5 & 61.2 & 67.4 & 64.3 & 62.3 & 62.9 & 64.3 \\
\hline Lithuania & 43.1 & 72.5 & 61.9 & 79.5 & 97.6 & 99.9 & 99.3 & 91.4 & 87.0 & 84.4 \\
\hline Luxembourg & 272.0 & 331.7 & 251.6 & 366.0 & 411.4 & 408.2 & 393.2 & 394.5 & 398.6 & 393.7 \\
\hline Hungary & 97.3 & 128.5 & 112.4 & 133.0 & 143.4 & 139.3 & 141.1 & 145.4 & 147.0 & 138.0 \\
\hline Netherlands & $:$ & 412.3 & 349.3 & 390.9 & 445.3 & 464.1 & 452.7 & 490.6 & 484.8 & 469.6 \\
\hline Austria & 213.0 & 257.8 & 236.4 & 257.8 & 285.7 & 285.7 & 286.3 & 284.7 & 284.7 & 287.7 \\
\hline Poland & 67.6 & 98.2 & 80.9 & 98.0 & 110.9 & 114.9 & 115.3 & 116.0 & 116.3 & 111.7 \\
\hline Portugal & 87.0 & 104.3 & 96.7 & 109.0 & 118.0 & 121.7 & 124.6 & 123.9 & 122.4 & 119.6 \\
\hline Romania & 25.1 & 45.0 & 40.2 & 48.8 & 53.7 & 53.5 & 56.3 & 58.4 & 61.0 & 62.1 \\
\hline Slovenia & 88.4 & 111.3 & 99.9 & 115.9 & 126.1 & 125.2 & 126.3 & 130.8 & 133.1 & 133.9 \\
\hline Slovakia & $:$ & 122.0 & 114.4 & 119.4 & 131.3 & 144.1 & 149.4 & 148.7 & 152.2 & 150.5 \\
\hline Finland & 302.2 & 355.7 & 292.7 & 333.2 & 357.7 & 364.9 & 383.4 & 374.7 & 365.9 & 366.5 \\
\hline Sweden & 209.4 & 255.3 & 212.6 & 272.6 & 302.4 & 332.0 & 329.8 & 327.6 & 332.5 & 332.5 \\
\hline UK & : & 225.9 & 195.1 & 222.6 & 235.3 & 253.9 & 246.1 & 257.8 & 281.6 & 271.2 \\
\hline
\end{tabular}
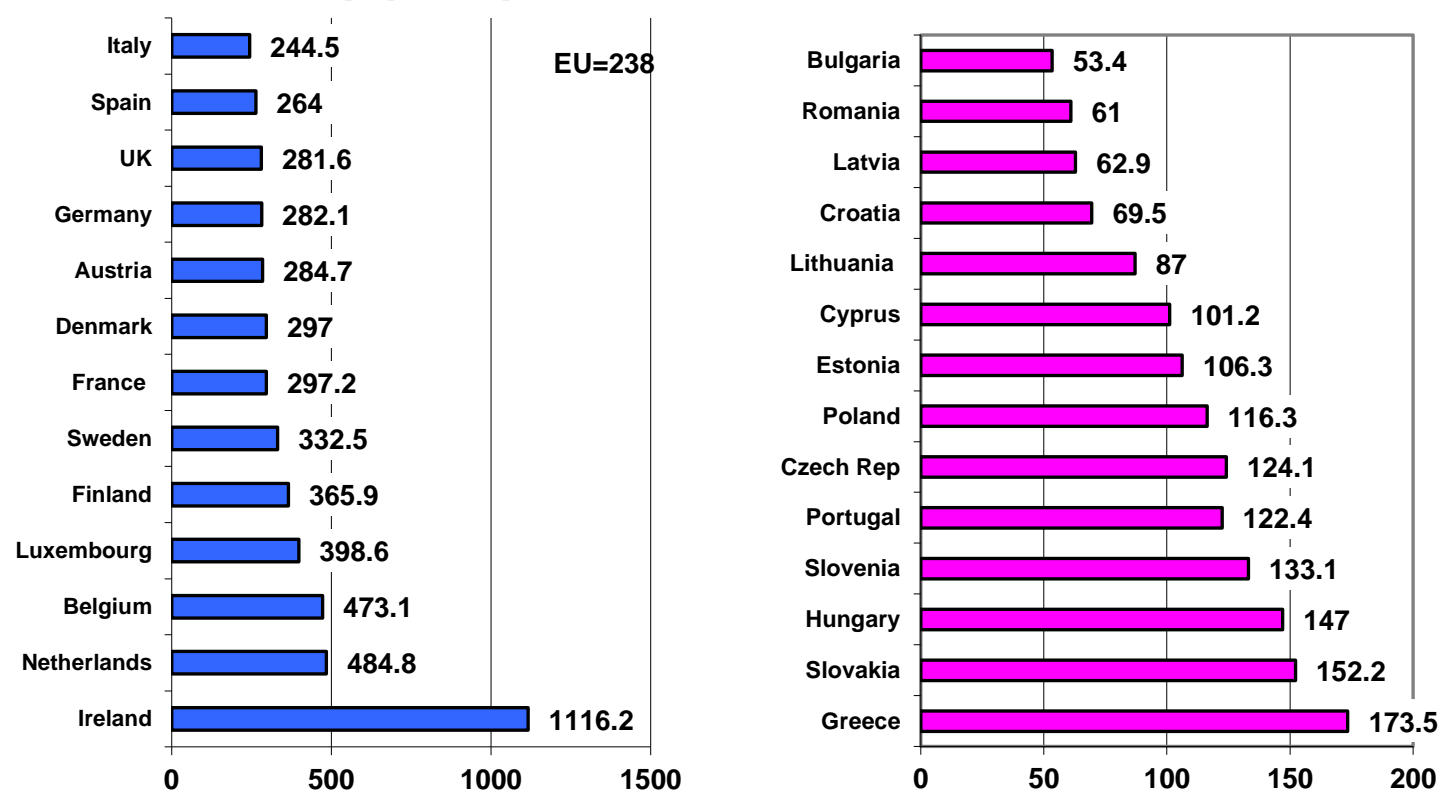

All countries had exceeded turnover per person employed after the crisis the level of 2008, except Cyprus. From 2005 it was grown two times in Bulgaria, Estonia, Latvia, Lithuania and Romania, and 1.7 times in Poland. In 
absolute terms, from 2008 to 2015, the highest turnover per person employed was Ireland, EUR 1116.2. At the same time, Ireland was more than twice as large as the Netherlands. The largest industrialized countries had higher productivity in France and Germany, the Nordic countries Finland and Sweden, the CEE countries Slovakia and the Baltic countries Estonia.

Turnover per person employed was higher in the medium-sized countries Ireland (1116.2), Netherlands (484.8), Belgium (473.1), and others. Great countries it is higher in Germany (282.1), but still more than 3 times smaller than Ireland. Smaller turnover per person employed was in new the EU Member States: Bulgaria (53.4), Romania (61.0), Latvia (62.9), Croatia (69.5) and in the old Member States Portugal (122.4). The differences were highly significant: the productivity of Ireland was 21 times higher than of Bulgaria.

In the new EU Member States in the last 10 years it has grown strongly, in the Baltic States, Bulgaria, Romania and Poland more than doubled. In the old Member States, where labour productivity was already relatively high, the increase was slower.

This is also the main reason why the wages in the new Member States are still several times lower than in the old - low productivity. High productivity was also found in the EFTA countries of Switzerland and Norway.

For a partial overview of the manufacture by sector has been taken as a basis the EU28 medium and Germany as the largest industrialized country in Europe in the 2016 period. We compare them with the country with the highest productivity data in this sector.

We see, that the most the greatest work efficiency manufacture sectors are in Netherlands. Germany and Ireland are not one of the leaders in the highest productivity of the manufacture sector. But of total is leader Germany, where is also high productivity, but not EU top-max.

Turnover per person employed graphs and formulas (Gross Domestic Product At Current Prices)

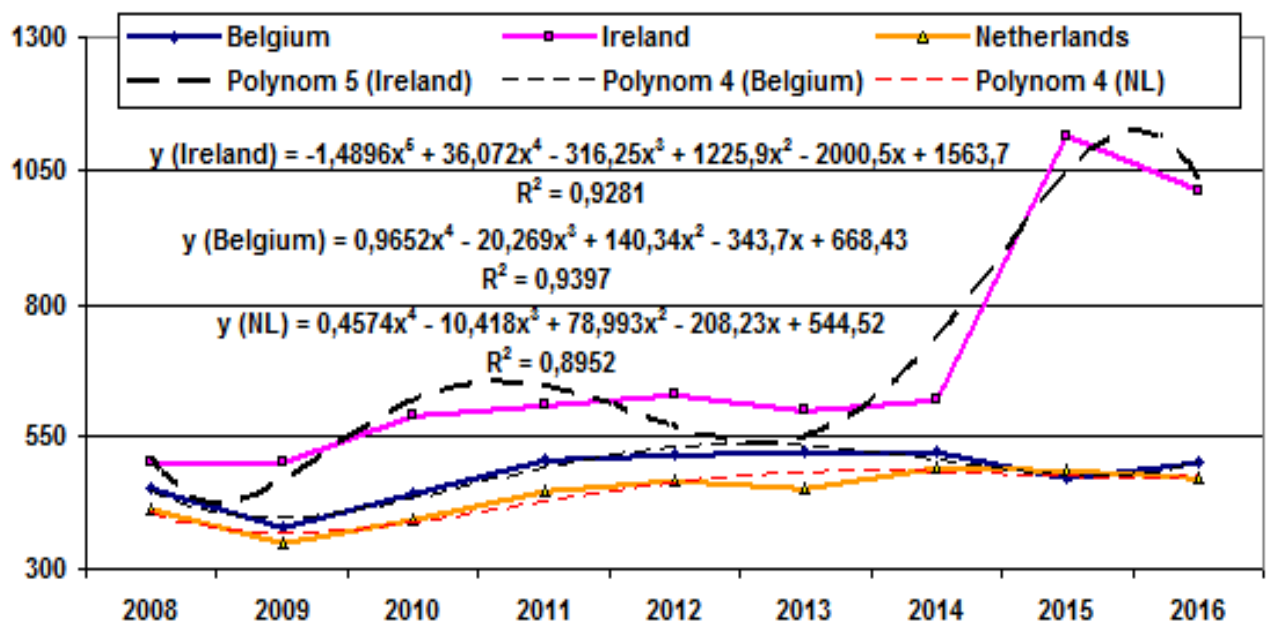

Ireland $y=-0.5828 x^{6}+15.994 x^{5}-168.43 x^{4}+859.91 x^{3}-2211.9 x^{2}+2708.9 x-709.1 ; R^{2}=0.9789$ $y=-1.4896 x^{5}+36.072 x^{4}-316.25 x^{3}+1225.9 x^{2}-2000.5 x+1563.7 ; R^{2}=0.9281$

Belgium $y=0.9652 x^{4}-20.269 x^{3}+140.34 x^{2}-343.7 x+668.43 ; R^{2}=0.9397$

Netherlands (NL) $y=0.4574 x^{4}-10.418 x^{3}+78.993 x^{2}-208.23 x+544.52 ; R^{2}=0.8952$

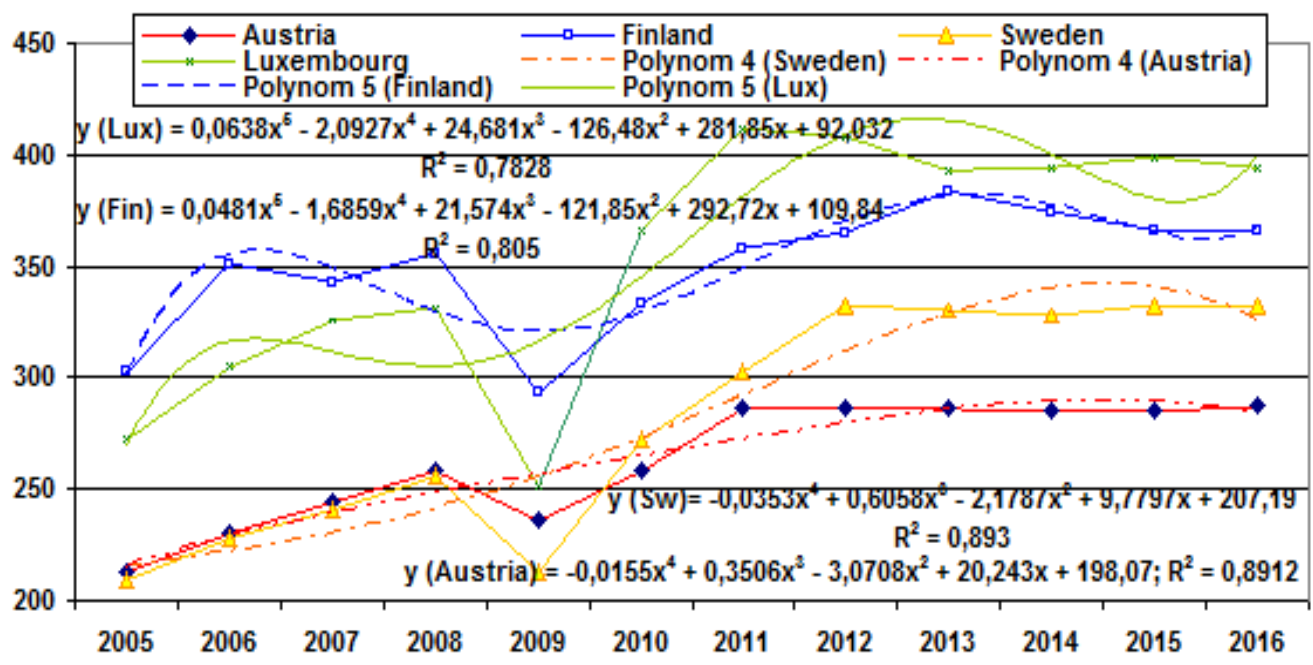

Luxembourg $y=-0.0091 x^{6}+0.4199 x^{5}-7.4627 x^{4}+64.01 x^{3}-270.05 x^{2}+519.9 x-40.036 ; R^{2}=0.7946$ $y=0.0638 x^{5}-2.0927 x^{4}+24.681 x^{3}-126.48 x^{2}+281.85 x+92.032 ; R^{2}=0.7828$

Finland $y=0.0021 x^{6}-0.0346 x^{5}-0.4385 x^{4}+12.439 x^{3}-88.504 x^{2}+237.43 x+140.51 ; R^{2}=0.8075$ $y=0.0481 x^{5}-1.6859 x^{4}+21.574 x^{3}-121.85 x^{2}+292.72 x+109.84 ; R^{2}=0.805$ 
International Journal of World Policy and Development Studies

Sweden $y=0.0011 x^{6}-0.0035 x^{5}-0.6827 x^{4}+11.231 x^{3}-65.109 x^{2}+156.52 x+104.97 ; R^{2}=0.9341$

$y=0.0402 x^{5}-1.3414 x^{4}+16.056 x^{3}-82.721 x^{2}+185.72 x+88.773 ; R^{2}=0.9339$

$y=-0.0353 x^{4}+0.6058 x^{3}-2.1787 x^{2}+9.7797 x+207.19 ; R^{2}=0.893$

$y=-0,3123 x^{3}+5,7159 x^{2}-15,271 x+229,23 ; R^{2}=0,8888$

Austria $y=-0.0155 x^{4}+0.3506 x^{3}-3.0708 x^{2}+20.243 x+198.07 ; R^{2}=0.8912$

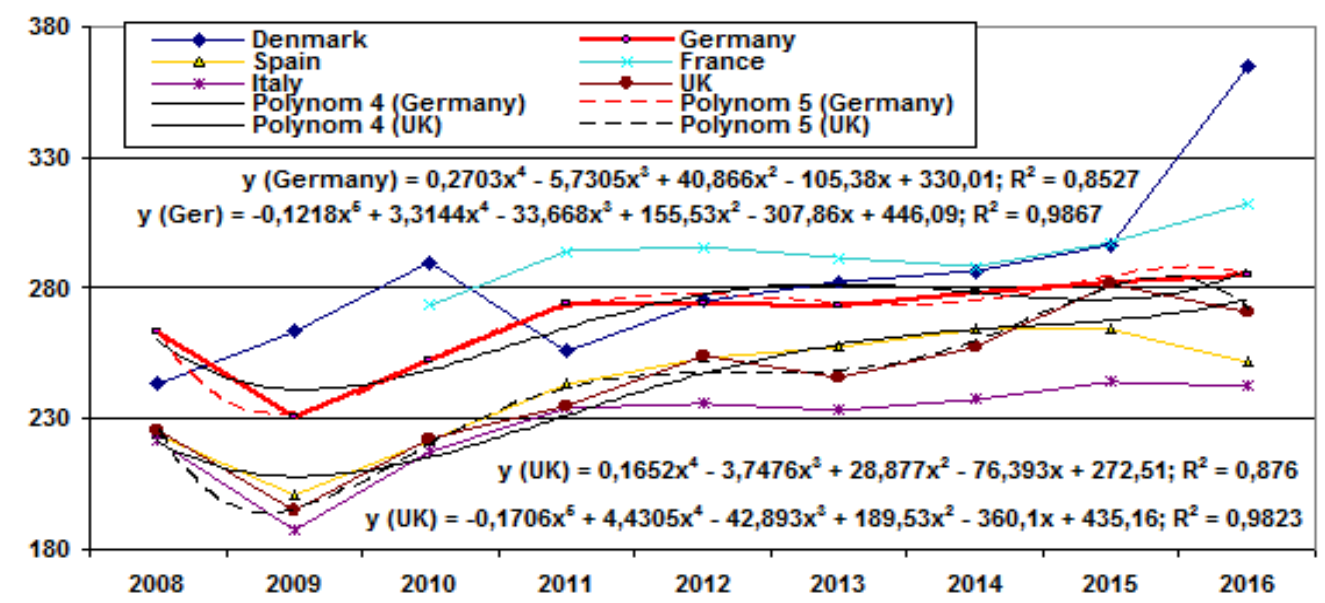

Germany $y=0.2703 x^{4}-5.7305 x^{3}+40.866 x^{2}-105.38 x+330.01 ; R^{2}=0.8527$

$y=-0.1218 x^{5}+3.3144 x^{4}-33.668 x^{3}+155.53 x^{2}-307.86 x+446.09 ; R^{2}=0.9867$

UK $y=0.1652 x^{4}-3.7476 x^{3}+28.877 x^{2}-76.393 x+272.51 ; R^{2}=0.876$

$y=-0.1706 x^{5}+4.4305 x^{4}-42.893 x^{3}+189.53 x^{2}-360.1 x+435.16 ; R^{2}=0.9823$

Table-4. Apparent labour productivity (Gross value added per person employed) of EU countries (Gross Domestic Product At Current Prices)

\begin{tabular}{|c|c|c|c|c|c|c|c|c|c|c|c|c|}
\hline & 2005 & 2006 & 2007 & 2008 & 2009 & 2010 & 2011 & 2012 & 2013 & 2014 & 2015 & 2016 \\
\hline Belgium & $\cdot$ & : & : & 83.9 & 80.4 & 89.3 & 87.1 & 89.9 & 95.7 & 98.9 & 103.5 & 1116 \\
\hline Bulgara & 5.0 & 5.3 & 7.0 & 6.7 & 6.7 & 7.7 & 8.6 & 8.9 & 9.1 & 9.9 & 11.4 & 13.0 \\
\hline Czech Rep & - & : & : & 23.2 & 21.6 & 24.3 & 25.8 & 25.7 & 25.9 & 27.3 & 28.3 & 29.0 \\
\hline Denmark & $:$ & : & : & 74.5 & 80.1 & 89.0 & 73.9 & 79.0 & 82.9 & 82.5 & 89.3 & 110.4 \\
\hline Germany & $:$ & : & : & 63.9 & 57.0 & 65.8 & 68.7 & 67.2 & 67.9 & 71.5 & 73.6 & 77.4 \\
\hline Estonia & 12.1 & 14.4 & 17.3 & 17.8 & 16.0 & 19.9 & 22.9 & 22.7 & 23.7 & 24.7 & 24.6 & 26.3 \\
\hline Ireland & $:$ & : & $\cdot$ & 159.3 & 166.8 & 189.6 & 200.0 & 207.9 & 196.6 & 194.1 & 441.7 & 406.5 \\
\hline Greece & : & : & : & 39.5 & 42.2 & 41.9 & 40.2 & 38.1 & 35.6 & 35.2 & 35.3 & 33.5 \\
\hline Spain & $:$ & : & : & 52.6 & 48.1 & 52.7 & 53.9 & 53.0 & 53.6 & 56.6 & 57.6 & 56.8 \\
\hline France & $:$ & : & $:$ & • & : & 62.5 & 63.8 & 63.9 & 64.2 & 66.7 & 71.7 & 73.6 \\
\hline Croatia & : & : & : & 19.3 & 17.4 & 17.6 & 17.5 & 17.4 & 17.4 & 18.2 & 19.2 & 21.8 \\
\hline Italy & $:$ & : & $:$ & 48.0 & 43.2 & 51.4 & 52.9 & 51.8 & 53.2 & 55.8 & 58.8 & 61.4 \\
\hline Cyprus & $:$ & : & 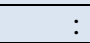 & 33.9 & 33.3 & 33.0 & 31.0 & 29.7 & 28.4 & 29.8 & 31.4 & 32.4 \\
\hline Latvia & 8.8 & 10.8 & 13.5 & 13.4 & 11.3 & 14.2 & 14.5 & 15.9 & 15.6 & 16.1 & 17.4 & 18.0 \\
\hline Lithuania & 9.7 & 9.9 & 12.2 & 11.6 & 11.5 & 14.0 & 15.6 & 15.0 & 14.5 & 15.8 & 19.1 & 19.6 \\
\hline Luxemboug & 73.6 & 76.1 & 94.1 & 84.3 & 58.2 & 70.4 & 72.5 & 70.8 & 70.8 & 75.8 & 78.1 & 92.8 \\
\hline Hungary & 21.1 & 22.0 & 24.2 & 25.5 & 23.3 & 26.7 & 28.1 & 26.9 & 28.0 & 29.3 & 30.6 & 29.5 \\
\hline Netherlans & : & : & 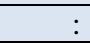 & 78.8 & 73.6 & 83.7 & 87.2 & 87.2 & 84.8 & 87.1 & 93.1 & 97.9 \\
\hline Austria & 67.0 & 71.6 & 75.8 & 73.8 & 68.0 & 75.5 & 79.7 & 78.4 & 76.9 & 79.3 & 82.6 & 86.5 \\
\hline Poland & 19.5 & 17.4 & 19.9 & 22.3 & 18.8 & 20.6 & 22.6 & 22.2 & 23.2 & 23.8 & 24.8 & 24.8 \\
\hline Portugal & 21.8 & 22.9 & 24.4 & 24.3 & 23.3 & 26.1 & 25.3 & 25.1 & 26.2 & 26.8 & 28.7 & 29.3 \\
\hline Romania & 5.6 & 7.0 & 9.2 & 11.0 & 9.6 & 11.3 & 11.4 & 11.5 & 12.0 & 13.4 & 12.8 & 14.0 \\
\hline Slovenia & 24.7 & 27.1 & 29.0 & 29.1 & 25.6 & 31.3 & 32.7 & 32.3 & 33.3 & 36.5 & 37.3 & 38.8 \\
\hline Slovakia & & . & 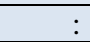 & 18.1 & 16.6 & 21.5 & 21.8 & 21.9 & 22.8 & 25.0 & 27.3 & 26.9 \\
\hline Finland & 74.4 & 82.4 & 81.6 & 76.0 & 58.0 & 71.5 & 69.7 & 65.5 & 69.6 & 70.8 & 74.0 & 81.2 \\
\hline Sweden & 59.8 & 64.2 & 67.5 & 66.8 & 57.9 & 77.4 & 80.4 & 81.2 & 82.8 & 83.2 & 90.1 & 89.9 \\
\hline UK & : & : & & 66.3 & 55.6 & 66.1 & 69.2 & 72.1 & 72.1 & 76.1 & 89.0 & 78.1 \\
\hline
\end{tabular}

Pre-crisis level exceeded in 2012 all countries, with the exception Croatia, Cyprus, Greece and Finland. Large variations were not. In 2009 no declined labour productivity in Ireland, Sweden and the UK, but also in Baltic States. 
Figure-7. EU and EFTA countries apparent labour productivity (Gross value added per person employed). 2015 (Gross Domestic Product At Current Prices)
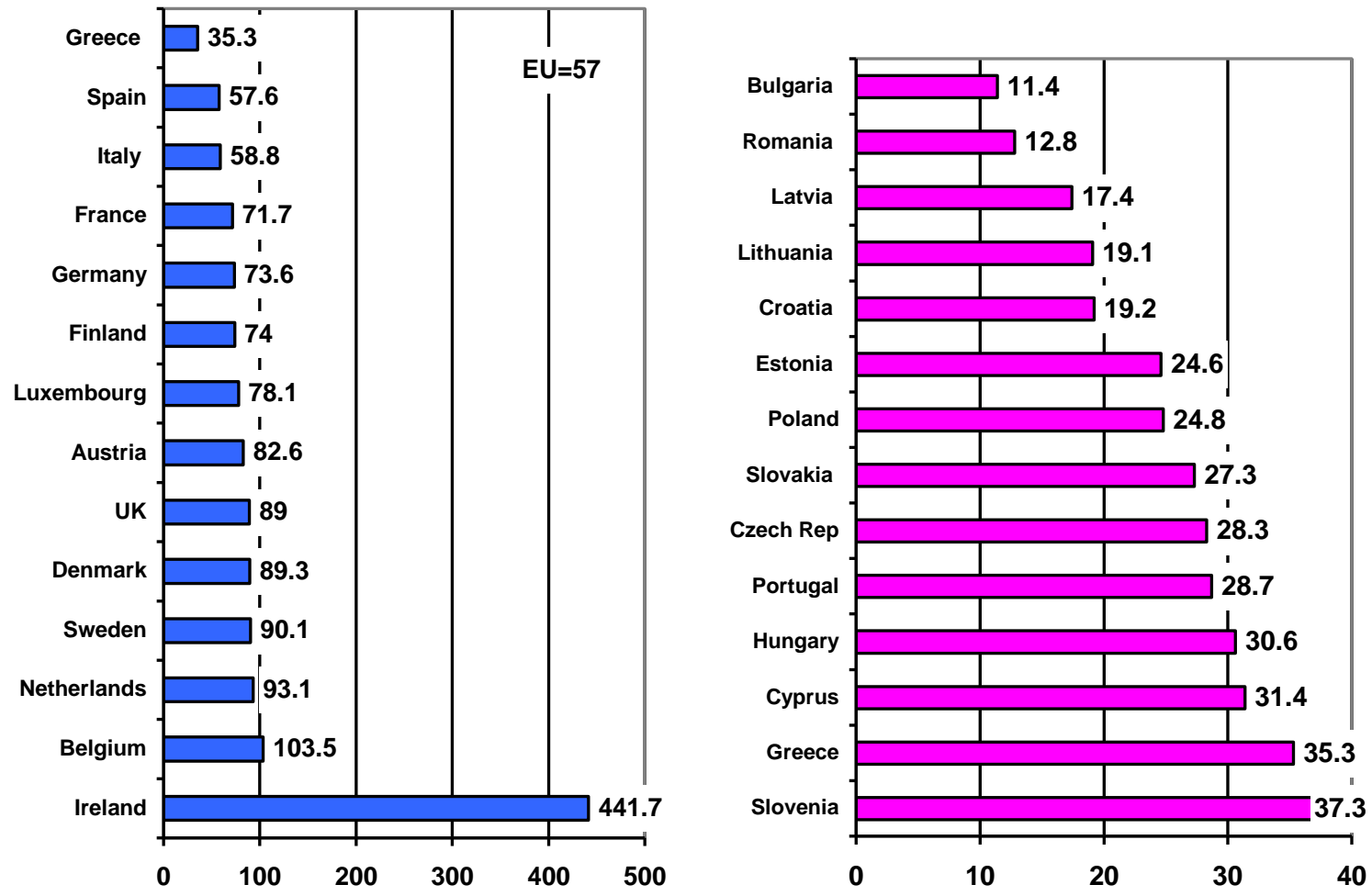

Apparent labour productivity (gross value added per person employed) was the highest in 2015 in Ireland (441.7), Belgium (103.5), Netherlands (93.1) and Sweden (90.1). In new the European Union Member States was greater apparent labour productivity in 2015 from CEE-8 countries Slovenia (37.3) and from Baltic States Estonia (24.6). Among the new members, it was also relatively high in Cyprus (31.4). Gross value added per person employed was lower in Bulgaria (11.4) and Romania (12.8). The differences were very large, up to 39 times. Over the years, this gap has increased.

Gross value added per person employed graphs and formulas (Gross Domestic Product At Current Prices)

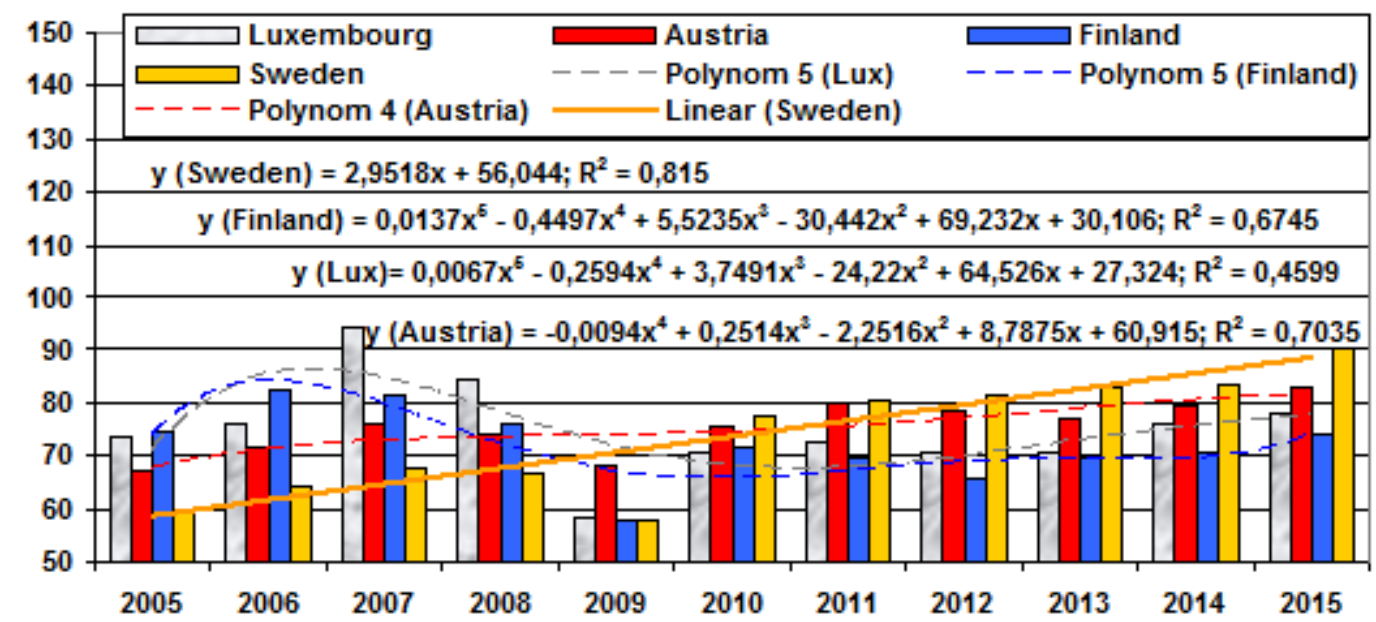

Sweden $y=0.0175 x^{5}-0.53 x^{4}+5.8296 x^{3}-28.037 x^{2}+58.313 x+23.582 ; R^{2}=0.8936$

$y=-0.005 x^{4}+0.0838 x^{3}-0.2121 x^{2}+1.4263 x+59.982 ; R^{2}=0.8286$

$y=-0.0365 x^{3}+0.7451 x^{2}-1.4002 x+62.327 ; R^{2}=0.8277$

$y=0.0885 x^{2}+1.8903 x+58.344 ; R^{2}=0.8207$

Luxembourg $y=0.0067 x^{5}-0.2594 x^{4}+3.7491 x^{3}-24.22 x^{2}+64.526 x+27.324 ; R^{2}=0.4599$

$y=0.0079 x^{6}-0.2773 x^{5}+3.703 x^{4}-23.188 x^{3}+67.553 x^{2}-78.782 x+103.4 ; R^{2}=0.5226$

Finland $y=0.0137 x^{5}-0.4497 x^{4}+5.5235 x^{3}-30.442 x^{2}+69.232 x+30.106 ; R^{2}=0.6745$

Austria $y=0.0104 x^{5}-0.3205 x^{4}+3.6558 x^{3}-18.738 x^{2}+42.492 x+39.348 ; R^{2}=0.8157$

$y=-0.0094 x^{4}+0.2514 x^{3}-2.2516 x^{2}+8.7875 x+60.915 ; R^{2}=0.7035$ 


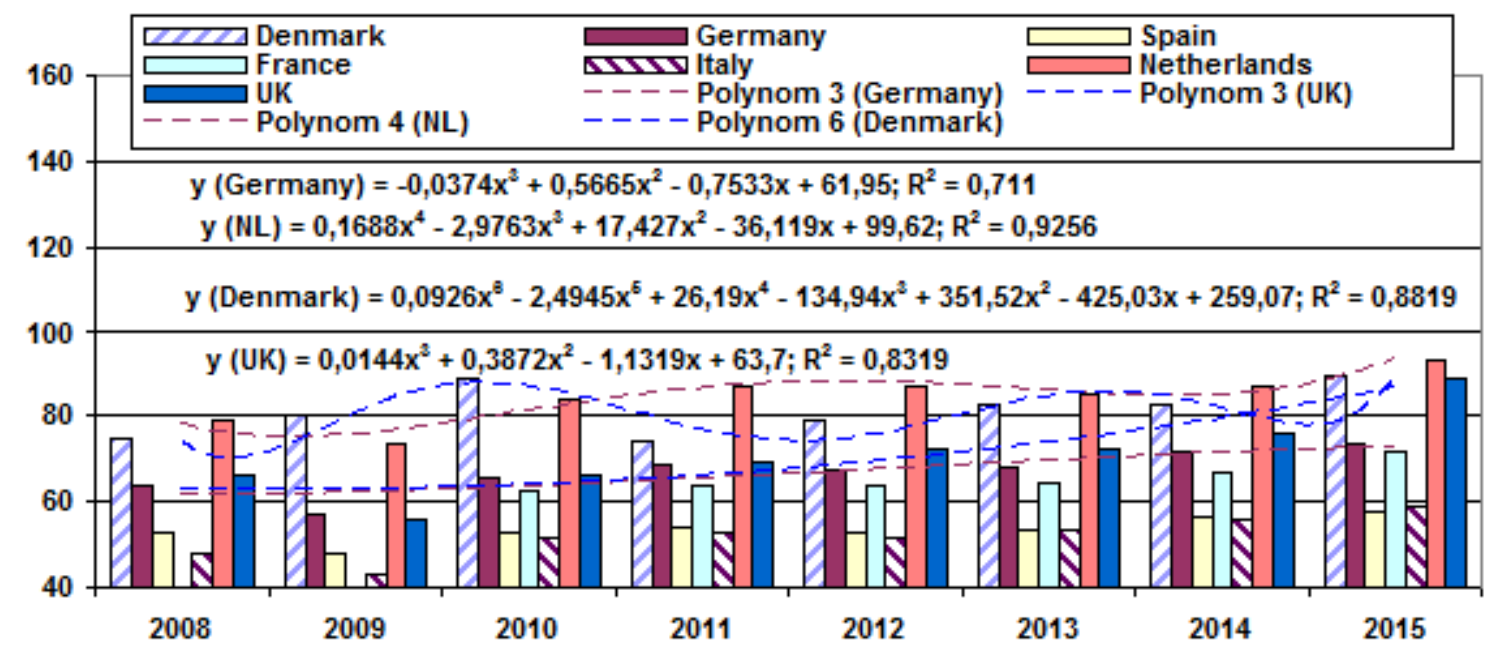

Germany $y=0.108 x^{4}-1.9806 x^{3}+12.303 x^{2}-27.68 x+80.271 ; R^{2}=0.8291$

$y=-0.0374 x^{3}+0.5665 x^{2}-0.7533 x+61.95 ; R^{2}=0.711$

$\mathrm{UK} y=0.0144 x^{3}+0.3872 x^{2}-1.1319 x+63.7 ; R^{2}=0.8319$

NL $y=0.0629 x^{3}-0.9292 x^{2}+5.996 x+70.964 ; R^{2}=0.7169$

$y=0.1688 x^{4}-2.9763 x^{3}+17.427 x^{2}-36.119 x+99.62 ; R^{2}=0.9256$

Denmark $y=0.0068 x^{5}-0.254 x^{4}+3.3893 x^{3}-19.619 x^{2}+48.081 x+42.3 ; R^{2}=0.595$

$y=0.0926 x^{6}-2.4945 x^{5}+26.19 x^{4}-134.94 x^{3}+351.52 x^{2}-425.03 x+259.07 ; R^{2}=0.8819$

There were basically same trends as gross value added per person employee. It was the highest on 2015 in Ireland (457.9), Belgium (110.9), Sweden (99.6) and Netherlands (99.2). It was lower in Bulgaria (11.9) and Romania (12.9). It was the highest in 2016 in Ireland (420.3), Belgium (112.6), Sweden (99.9) and Netherlands (104.4). It was lower in Bulgaria (13.6) and Romania (14.2).

The differences were very large, in 201538 times, but in 2016 only 31 times.

The same comment that was turnover per person employed also applies to this for apparent labour productivity.

Take the basics this publication and the previous work of the authors (Tanning L. and Tanning, 2008;2009;2012;2013a; Tanning T. and Tanning, 2013d; Tanning T. and Tanning, 2013e; Tanning L. and Tanning, 2013b; Tanning T. and Tanning, 2013f; Tanning L. and Tanning, 2013c;2014a;2014b;2014c;2014f;2014d;2014e; Tanning T. and Tanning, 2014h; Tanning and Tanning, 2015; Tanning T., 2017a;2017b; Tanning L. and Tanning, 2018a;2018b;2018c), we can make the following conclusions and suggestions.

\section{Conclusions}

$>$ Germany is largest European economy, also by manufacturing, the EU economic motor, which depends on development of most economic indicators throughout of EU.

$>$ Companies were brought out of the economic crisis by the growth of labour productivity.

$>$ The importance of large companies, especially those with 250 and more employees, was decisive.

$>$ Countries economy has increased after the crisis. Whether economic growth achieved smaller number personnel, it means expense labour productivity?

$>$ Number of persons employed of the EU from 2005 to 2015 was fall 12\%, decreased over 4 million persons.

$>$ Highest turnover per person employed was Ireland, Netherlands and Belgium. The largest industrialized countries had higher productivity in France and Germany, the Nordic countries Finland and Sweden, the CEE countries Slovakia and the Baltic countries Estonia.

$>$ In the new EU Member States in the last 10 years it has grown strongly, in the Baltic States, Bulgaria, Romania and Poland more than doubled. In the old Member States, where labour productivity was already relatively high, the increase was slower.

$>$ The greatest work efficiency manufacture sectors of the EU are in Netherlands.

$>$ Apparent labour productivity (gross value added per person employed) was the highest in Ireland, Belgium, Netherlands and Sweden. In new the EU Member States was it greater from CEE-8 countries Slovenia and from Baltic States Estonia.

$>$ The differences of labour productivity in the EU were very large.

$>$ This regression analysis has been used in relatively high productivity and stable economies countries. As the level of European economy is primarily determined by the great powers, they are also given more attention.

$>$ Labour productivity changes laws of manufacturing are very complicated. These mathematical models typically have 3rd to 5 th degree polynomials curve, with no linear dependency.

$>$ The suitability of a polynomial curve is evaluated using the methods of classical regression analysis: the higher the $\mathrm{R}^{2}$, the more accurate the mathematical model for assessing dependence.

$>$ If the difference in $\mathrm{R}^{2}$ for a polynomial curve of different degrees was small, was selected simpler mathematical model with a lower degree of polynomial. 
$>$ For all regression analysis cases discussed here, the polynomial degree was greater than 0.45 . It is characterized by a relatively stable economy in these countries, which proceeds according to certain rules.

$>$ In individual cases, $\mathrm{R}^{2}$ has approached to 1 , therefore, the functional relationship.

$>$ Very big $\mathrm{R}^{2}$ were Germany: polynomial curve of GDP - simple 2nd degree polynomial, where $\mathrm{R}^{2}=0.9422$; the curve of turnover per person employed is a complex 5th-level polynomial where $\mathrm{R}^{2}=0.9867$. Very big $\mathrm{R}^{2}$ of curve of turnover per person employed 5th-level were the UK =0.9823; Sweden $=0.9339$; Ireland = $0.9281\left(6^{\text {th }}\right.$ degree $\left.=0.9789\right)$ and 4 th-level were Belgium $=0.9397$.

$>$ Regression analysis was also used by independent variables by stable Belgium. Polynomials of varying degrees could be shifted to predict for up to 3 years. This method showed up to three times the drop or increase in the current degree polynomial, depending on the level of the indicator. This is absurd. Because the changes in the real economy is relatively complex, which is characterized by polynomials, then can be done the conclusion: the independent variables method is not suitable for economic analysis making forecasts.

$>$ At the same time, knowing the laws of labour productivity changes allows you to make optimal decisions both in the economy and in politics.

\section{References}

Annual Detailed Enterprise Statistics for Industry (2018). Turnover or gross premiums written. Manufacturing. Code, sbs_na_ind_r2.: Available: http://appsso.eurostat.ec.europa.eu/nui/show.do?dataset=sbs_na_ind_r2\&lang=en

Ash, N. S. (2009). Data analysis using microsoft excel. New Delhi.

Bethea, R. M., Duran, B. S. and Boullion, T. L. (1985). Statistical methods for engineers and scientists. Marcel Dekker. ISBN: New York.

Dodge, Y. (2003). The Oxford dictionary of statistical terms.

Extrapolation Methods (1991). Theory and Practice by C. Brezinski and M. Redivo Zaglia, North-Holland.

Formulas of Productivity Measures (2018). Statistics estonia. Available: http://pub.stat.ee/pxweb.2001/I_Databas/Economy/09Financial_statistics_of_enterprises/04 Enterprises_financial_key/02Annual_statistics/FS_0 08.htm

Freedman, D. A. (2005). Statistical models, Theory and practice. Cambridge University Press.

Gross Domestic Product At Current Prices, B., PPS. Code: tec00001. Eurostat. http://ec.europa.eu/eurostat/tgm/table.do?tab=table\&init=1\&language=en \&pcode=tec00001\&plugin=1

Kalle, E. (2013). Tootlikkusealane evolutsioon Eestis. The evolution of productivity in Estonia. Tallinn University of Technology.

Lindley, D. V. (1987). Regression and correlation analysis. New Palgrave, A Dictionary of Economics. 4: 120-23.

Manufacturing Encyclopaedia britannica. http://www.britannica.com/EBchecked/topic/849534/manufacturing

Meade, N. and Islam, T. (1995). Prediction intervals for growth curve forecasts. Journal of Forecasting, 14(5): 41330 .

Methodological Notes (2011). The european union labour force survey EU-LFS., Statistics in focus. Eurostat. 11.

Methodology Annual accounts. National accounts, including GDP. Eurostat. http://epp.eurostat.ec.europa.eu/portal/page/portal/national_accounts/methodology

Productivity, O.: Available: http://stats.oecd.org/Index.aspx?DatasetCode=PDYGTH

Saari, S. (2011). Production and productivity as sources of well-being. MIDO OY. 25. Available: http://www.mido.fi/index tiedostot/

Schittkowski, K. (2002). Data fitting in dynamical systems. Kluwer: Boston.

Scott Armstrong, J., Fred, C. and Thomas, Y. J. (2004). Decomposition by causal forces, A procedure for forecasting complex time series. Available: http://www.forecastingprinciples.com/paperpdf/Decomposition\%20by\%20Causal\%20Forces.pdf

Seber, G. A. F. and Wild, C. J. (1989). Nonlinear regression. John Wiley and Sons: New York.

Structural Business Statistics Introduced Eurostat. Available: http://ec.europa.eu/eurostat/statisticsexplained/index.php/Manufacturing_statistics__NACE_Rev. 2

Tanning and Tanning (2015). The economic crisis lessons of Europe. LAP. Lambert Academic Publishing: Saarbrücken, Germany.

Tanning, L. and Tanning, T. (2008). Uus Euroopa Liit - 27, New European Union - 27. Tallinn University of Technology: Tallinn.

Tanning, L. and Tanning, T. (2009). Rahvusvaheline majandus, Part I, International economy I. Tallinn University of Technology: Tallinn.

Tanning, L. and Tanning, T. (2012). Baltic states problem - labour market, Analysis employment, Unemployment and vacancies of Estonia, Improved beveridge curve. International Journal of Business and Social Science, USA: $36-56$.

Tanning, L. and Tanning, T. (2013a). An analysis of labour productivity in Central and East European countries. International Journal of Arts and Commerce, 2(1): 1-18.

Tanning, L. and Tanning, T. (2013b). How the baltic states transportation companies survived the economic crisis, The lessons of crisis. International Journal of Operations and Logistics Management, 2(4): 14-32. 
Tanning, L. and Tanning, T. (2013c). Working efficiency before and after the economic crisis in the Baltic States. Global Business and Economics Research Journal, Jakarta, Indonesia, 2(5): 92-101.

Tanning, L. and Tanning, T. (2014a). Central and Eastern European Countries before and after the 2008 financial crisis, Economic overview and transportation companies. Journal of Business Theory and Practice, 2(2): 221.

Tanning, L. and Tanning, T. (2014b). The European competitiveness the economic crisis lessons of transportation enterprises in Poland and other Central and Eastern Europe Countries. International Journal of Economics, Finance and Management, 3(4): 164-76.

Tanning, L. and Tanning, T. (2014c). Gross value added per person analyses of transportation companies of new European Union countries in 2005-2011. SOP, Transactions on Marketing Research, USA, 1(2): 1-15.

Tanning, L. and Tanning, T. (2014d). Labour productivity analyses of gross value added and turnover per person employed of transportation companies of European Countries in 2005 - 2011. American Association for Science and Technology. USA. International Journal of Economic Theory and Application, 1: 9-18.

Tanning, L. and Tanning, T. (2014e). Labour productivity of transportation enterprises by turnover per person employed before and after the economic crisis, Economic crisis lessons from Europe. American International Journal of Contemporary Research, 4(1): 52-76.

Tanning, L. and Tanning, T. (2014f). How former post-socialist countries have been the economic crisis? SOP Transactions on Economic Research, USA: 15-33.

Tanning, L. and Tanning, T. (2018a). Central and Eastern European countries value added analysis. American institute of science. American Journal of Business and Society. Boston. USA, 3(2): 38 - 57.

Tanning, L. and Tanning, T. (2018b). European union versus united kingdom based on the economy. 1 vols.: International Technology and Science Publications: London. 2: http://www.itspoa.com//UploadFiles/201802/369/2018022615432038101.pdf

Tanning, L. and Tanning, T. (2018c). Polish and baltic states passenger transport analysis. American institute of science. American Journal of Business and Society. Boston. USA, 3(2): 58 - 71.

Tanning, T. (2017a). Contradictions are the basis for development. GISAP, Economics, Jurisprudence and Management. IASHE. London.

Tanning, T. (2017b). Correlation between individual and collective needs in the context of the Brexit. GISAP, Economics, Jurisprudence and Management. IASHE. London:

Tanning, T. and Tanning, L. (2013d). The analysis of labour productivity in East European countries. Journal of Technology, Education, Management, Informatics, 2(2): 136-41.

Tanning, T. and Tanning, L. (2013e). An analysis of working efficiency in Central and East European Countries. The Scientific \& Academic Publishing, New York, USA. American Journal of Economics 3(3): 171-84.

Tanning, T. and Tanning, L. (2013f). Why Eastern European wages are several times lower than in Western Europe? Global Business and Economics Research Journal, Jakarta, Indonesia, 2(1): 22-38.

Tanning, T. and Tanning, L. (2014g). Labour productivity trends analyses in Baltic countries to 2014. International Journal of Economic Theory and Application. American Association for Science and Technology. USA, 1(3): $35-42$.

Tanning, T. and Tanning, L. (2014h). Material flow efficiency of Central and East European countries of the European Union. Berlin, Germany. Journal of Multidisciplinary Engineering Science and Technology JMEST, 1: 262-72.

Wooldridge, J. (2012). Introductory econometrics, A modern approach. South-Western Cengage Learning: Mason, $\mathrm{OH}$.

Zhao, S., Yang, K. and Yang, X. (2011). Reconstruction from truncated projections using mixed extrapolations of exponential and quadratic functions. J. Xray Sci. Technol.: 155-72. Available: http://imrecons.com/wpcontent/uploads/2013/02/extrapolation.pdf 